DOI: $10.17805 /$ zpu.2018.3.19

\title{
Социально-психологический подход к исследованию социальной активности молодежи
}

\author{
E. С. БАЛАБАНОВА \\ МОСКОВСКИЙ ГУМАНИТАРНЫЙ УНИВЕРСИТЕТ
}

Социально-психологический подход к исследованию феномена социальной активности молодежи основан на понимании значимости условий социальной среды, включенности молодежи в социальные группы и опыта организации совместной жизнедеятельности для определения психологического содержания и структуры социальной активности школьников и студентов. В исследовании психологических особенностей социальной активности молодежи разных социальных групп единицами анализа выступают представления о социальной активности, отношение к разным видам и формам социальной активности, уровни проявления социальной активности, а также ценностные ориентации молодежи, направленность личности и мотивы социальной активности.

Материалом для анализа выступили результаты авторских эмпирических исследований, которые проводились в 2014-2017 гг. среди учащихся школ и вузов г. Москвы.

Представления молодежи о социальной активности обусловлены формами и видами социальной деятельности, которые практикуются в молодежных объединениях и образовательных организациях, а также сферами жизнедеятельности социальных групп. Факторами, определяющими уровень социальной активности молодежи, выступают инициативность, интерес к деятельности, ее вид, знания, навыки и умения в этом виде деятельности, наличие организаторских способностей. Инициативность рассматривается как интегральное качество личности лидера, а его ценностные ориентации и направленность личности как характеристики, определяющие вектор инициативы, сферы активности и типы лидерства. Ведущей направленностью личности социально активной молодежи является направленность «на себя». Выраженность иных типов направленности личности: «на другого человека», «на сохранение отношений», «на дело» и «на позицию» - находится в зависимости от пола молодежи и ее принадлежности к социальной группе. Мотивы социальной активности различаются у молодежи разного пола и проявляются в стремлении к свободе, благополучию и престижу - у юношей, и в стремлении к положительной оценке, помощи другим, служению обществу - у девушек. Также для девушек характерен рост мотива карьеры при высокой степени значимости результата выполняемой ими социальной деятельности.

В целом социальная активность молодежи обусловлена индивидуально-психологическими и личностными особенностями юношей и девушек и актуальным для них социальнопсихологическим пространством.

Ключевые слова: социальная активность; формы социальной активности; социальная активность молодежи; уровни социальной активности; ценностные ориентации; направленность личности; мотивация социальной активности

\section{ВВЕАЕНИЕ}

$\prod$ редметом социальной психологии, по мнению А. А. Журавлева, являются «псидивида и группу как субъектов социального взаимодействия» (Журавлев, 2002: 6). Фокусом социально-психологического анализа выступают психологические особенности личности, обусловленные фактом ее включения в различные социальные группы, и специфика внутригрупповых отношений. Аля формирования личности имеет значение, с одной стороны, позиция и статус в той или иной общности людей, с другой - система групповых мнений, представлений, норм, ценностей этих групп членства. По мнению Б. А. Парыгина суть социально-психологического подхода заключается в том, чтобы «раскрыть всю структурную сложность личности, которая являет- 
ся одновременно как объектом, так и субъектом общественных отношений...» (Парыгин, 1971: 109).

Аля понимания психологического содержания и структуры феномена социальной активности важным является использование социально-психологического подхода, позволяющего определить специфику поведения личности, связанную с «потребностью самореализации (личности)... в отведенной для нее жизни, пространстве и времени» (Парыгин, 1999: 153).

Согласно методологическим представлениям Е. В. Шороховой, существует группа социально-психологических показателей и факторов, через которые может быть описана специфика поведения человека, а также закономерности проявления и формирования социальной активности. $\mathrm{K}$ ним можно отнести социальную детерминацию личности и ее поведения, социально-психологические и социально-демографические особенности личности, ее психический склад и жизненную позицию (Шорохова, 1975).

В социальной психологии понятие социальной активности личности исследователи используют, характеризуя активность человека в жизнедеятельности социальных групп и общества в целом. На сегодняшний день у исследователей феномена социальной активности не существует единого взгляда на его содержание и структуру. Однако в определение социальной активности, наряду с особенными характеристиками, они единогласно включают осознаваемое, целенаправленное взаимодействие личности и социума, подчеркивают ее сложное социально-психологическое содержание и специфику мотивации. Также они отмечают, что в конкретных формах социальной активности раскрывается взаимосвязь самоопределения и субъектных качеств личности, проявляется система отношений человека к окружающей действительности (Купрейченко, Моисеев, 2010).

В данном исследовании социально-психологический подход к рассмотрению социальной активности заключается в установлении ее структуры и содержания через определение психологических характеристик, социопсихологических детерминант, а также личностных и групповых факторов проявления социальной активности. Важным является положение о том, что социальная активность проявляется в осознаваемой активной жизненной позиции, которую человек занимает, исходя из своего социального статуса и актуальной социальной ситуации. Аругим основополагающим представлением, на которое опирается программа исследования, является понимание субъектных качеств личности и системы отношений личности к окружающей действительности во взаимосвязи с потребностями, ценностными ориентациями и установками личности, а также требованиями социальной среды.

Существуют исследования социальной активности молодежи, проведенные в разное время и представляющие интерес для социально-психологического анализа данного феномена. Результаты исследований обнаруживают определенные различия в психологической структуре и факторах социальной активности, в ее мотивации и ценностно-смысловой направленности. Они связаны с особенностями потребностной сферы, ценностных и смысложизненных ориентаций, направленности личности молодежи в разные временные периоды. Также исследователями подчеркиваются различия в формах социальной активности личности, которые обусловлены видами социальной деятельности, а также спецификой социальных групп, в которые включена личность (Косарев, 1970; Купрейченко, Моисеев, 2010; Мальковская, 1988; Федорова, 2000). 
Специально разработанная программа комплексного исследования личностных и групповых факторов социальной активности молодежи включала опрос с применением специальных психодиагностических методик, а также использование метода незаконченных предложений. Согласно программе исследования, единицами анализа социальной активности молодежи выступали представления молодежи о социальной активности, отношение молодежи к разным формам и направлениям социальной активности, уровни ее проявления, а также мотивация социальной активности и связанные с ней ценностные ориентации и направленность личности.

Предметом исследования являлись психологические особенности проявления социальной активности у молодежи разных социальных групп (школьников и студентов) и разного пола.

Анализ эмпирических данных проводился с помощью качественно-количественных методов, использовался метод контент-анализа и методы математической статистики.

Объектом комплексного исследования выступала молодежь в возрасте 15-25 лет, включенная в разные социальные группы - школьные классы (10-11-й классы), студенческие группы (1-4-й курсы). Сбор әмпирических данных проводился в средних и высших учебных заведениях г. Москвы в течение 2014-2017 гг.

В настоящее время исследовательский интерес вызывает то направление социальной активности молодежи, которое связанно с просоциальным поведением, т. е. с поведением, приносящим пользу другим людям или обществу. Таким образом, важным является не только психологическая характеристика социальной активности, но и определение тех мотивационных образований и факторов, которые побуждают и направляют личность на совершение полезных для других людей и общества в целом действий и поступков.

В связи с этим целью данной публикации является анализ части результатов комплексного эмпирического исследования, полученных на выборке представителей школьного и студенческого самоуправления, а также обобщение результатов исследования мотивации социальной активности (Балабанова, 2015, 2016) с учетом психологических особенностей социально активной молодежи в зависимости от ее принадлежности к различным социальным группам.

Анализу подлежит эмпирический материал, полученный на отдельной выборке, которую составили 120 человек - участники школьного и студенческого самоуправления, из них: студенты - 70 чел., школьники - 50 чел., юноши - 60 чел. и девушки - 60 чел.

\section{ПРЕАСТАВАЕНИЯ МОАОАЕЖИ О СОЦИААЬНОЙ АКТИВНОСТИ}

Аля понимания реального существования и жизнедеятельности молодежи, а также оснований для проявления социальной активности необходимо знать содержание когнитивного компонента социальной активности, т. е. установить, что молодежь думает о своей активности и какими образами наделяет себя социально активная молодежь. Аанное положение легло в основу исследования представлений молодежи о социальной активности, где в фокусе анализа оказались представления молодежи о социальной активности и представления личности о себе как о субъекте социальной активности.

Полученные с помощью метода незаконченных предложений и контент-анализа смысловые категории выстроились в определенную структуру представлений школь- 
ников и студентов о социальной активности (представлены по убыванию частоты встречаемости): 1) «общественная деятельность»-55,8\% от общей выборки; 2) «личностная особенность человека» - 43,2\%; 3) «общение, коммуникация» - 37,8\%; 4) «защита людей, помощь людям» - 35,2\% (у студентов әтот показатель незначительно выше, чем у школьников); 5) «интерес к людям и обществу» - 30,2\% всех респондентов. Аанные смысловые категории чаще других встречались в ответах респондентов обеих социальных групп. Можно сказать, что они составляют ядро представлений молодежи о социальной активности.

Студенты ассоциируют свою социальную активность в первую очередь с общественной деятельностью, личностной особенностью, эффективной коммуникацией и общением, социальным интересом и помогающим поведением. Аанный факт является важным для понимания особенностей восприятия студенческой молодежью сущности, содержания и смысла своей социальной деятельности, а также тех образов, которые формируются у студентов в отношении себя и своего окружения.

Смысловые категории, которые встречались в ответах респондентов в меньшей степени, но также вошли в структуру представлений молодежи о социальной активности, представлены последовательностью (по убыванию частоты встречаемости): 1) «быть в движении» - 26,01\% от общей выборки (у студентов более часто встречается, чем у школьников, $\mathrm{p}=0,002$, при $\mathrm{p} \leq 0,05) ; 2$ ) «созидание и труд» $-24,3 \%$; 3 ) «рациональное мышление» и «достижение целей»- 21,3\% (у студентов представлены в большей степени, чем у школьников, $\mathrm{p}=0,014$ и $\mathrm{p}=0,023$, при $\mathrm{p} \leq 0,05$ соответственно); 4) «развитие личности и реализация ее потенциалов» - 17,6\%; 5 ) «лидерство»$15,5 \%$ от всех респондентов.

Подобные ответы респондентов определяют некоторые особенности восприятия и понимания студентами своей социальной активности, где она в меньшей степени связана с созиданием и трудом, рациональным мышлением и движением к цели, развитием и реализацией лидерского потенциала.

Аалее проанализируем смысловые категории представлений о социальной активности студентов и школьников, которые встречались реже, чем все другие, и составили третью группу - периферическую часть структуры представлений о социальной активности: 1) «мое будущее»-10,5\% всей выборки (у школьников больше, чем у студентов, $\mathrm{p}=0,041$, при $\mathrm{p} \leq 0,05) ; 2$ ) «творчество и новаторство» и «совместность» - $11,5 \%$; 3 《досуг» - $10,2 \%$;) «толерантность»-9,2\%; 5) «самостоятельность и независимость»-7,1\%; 6) «членство в общественных организациях» и «неравнодушие» - 5,2\% (первая представлена исключительно у студентов, вторая, у школьников).

Так, в исследовании определено, что студенческая молодежь в меньшей степени ассоциирует социальную активность с самостоятельностью и независимостью. Кроме того, для студентов оказалось незначимым членство в общественных организациях. Однако в какой-то мере они связывают социальную активность со своим будущим, с творчеством и новаторством, совместностью и приятным досугом.

По сравнению со студентами школьники в некоторой степени понимают социальную активность как часть своего будущего и связывают ее с неравнодушным отношением к людям, группе, обществу. То есть в их представлениях о социальной активности присутствуют некоторые тенденции просоциального поведения. Выявленные значимые различия по исследуемым показателям в разных социальных группах респондентов определенным образом характеризуют смысл жизнедеятельности, а также 
особенности восприятия школьниками и студентами себя как субъектов социальной деятельности.

Таким образом, результаты исследования представлений молодежи о социальной активности показывают, что у студентов и школьников структура представлений о социальной активности имеет ряд сходств, а также некоторых различий. Так, в ядре представлений студентов о социальной активности не отражен ряд важных ее компонентов и проявлений, в частности командная работа, коллективная совместность и сплоченность, а также отзывчивость и связанные с ней сострадание и сочувствие. Аля них социальная активность в большей степени связана с социальным обучением, самореализацией и личными достижениями. Социальная активность школьников в первую очередь ориентирована на их будущее и на развитие лидерских качеств, также она связана с проявлением альтруизма и неравнодушного отношения к другим. Можно предположить, что указанные тенденции определяются особенностями социальных практик молодежи в общественных объединениях, а также сферами жизнедеятельности, в которых реализуются разные формы и направления социальной активности студентов и школьников в образовательных организациях (Соколова, 2010).

\section{ОТНОШЕНИЕ МОАОАЕЖИ К РАЗНЫМ ФОРМАМ СОЦИААЬНОЙ АКТИВНОСТИ}

Социальная активность проявляется и развивается в конкретных видах деятельности. В соответствии с характером и содержанием разных видов деятельности определяется ее специфика. Приобретая опыт социальной деятельности, личность включается в разные системы отношений, что способствует изменению форм социальной активности. Отношение к социальной активности определяется ее содержанием и направленностью, а также тем, насколько она отвечает объективным интересам человека, насколько удовлетворяет его потребности, какие эмоции он испытывает от процесса и результата своей деятельности.

Стремление молодежи к самостоятельному участию в жизни общества происходит по многим направлениям деятельности, которые определяют широкий спектр форм социальной активности. К наиболее распространенным формам социальной активности молодежи относятся участие в жизни своей социальной группы, лидерство, оказание помощи людям (волонтерство, благотворительность), выражение активной гражданской позиции, защита окружающей среды, социальная инициатива и социальное проектирование, участие в молодежных движениях, общественных организациях, самоуправлении.

Результаты исследования показали, что наиболее предпочитаемыми для школьников являются следующие направления и формы социальной деятельности, выявленные с помощью контент-анализа данных, полученных по методике незаконченных предложений. Как предпочитаемые определились следующие формы активности: «делать что-то полезное и кому-то нужное», «участвовать в жизнедеятельности своей группы», «участвовать в социально значимых и социально полезных программах», «добровольно помогать другим людям». Можно сказать, что в целом старшеклассники выбирают социально значимое направление деятельности и ищут возможности для проявления просоциальных форм активности, в том числе помогающего поведения.

В студенческой среде о выраженном стремлении к повышению своего социального статуса, к лидерским и руководящим позициям свидетельствуют следующие актуальные формы активности: «быть лидером студенческой группы, возглавлять какое-то 
направление деятельности в организации» и «быть организатором мероприятий». Однако направления социальной активности, связанные с реализацией инициативы, раскрытием потенциалов и обменом знаниями, оказываются не востребованными студенческой молодежью. Вероятно, в ряде московских вузов не созданы благоприятные условиях для реализации таких форм активности, как «выступать с инициативами» и «быть наставником, куратором младших». Аанные формы активности представлены у студентов в меньшей степени по сравнению со школьниками.

Исследователи социальной активности выделяют ее специфические формы, ориентируясь на сферы жизнедеятельности разных социальных групп и общества в целом. Так, известны политическая активность, гражданская активность, культурная активность, творческая активность, трудовая активность, деловая активность и т. А. (Мальковская, 1988).

Анализ социальной активности молодежи по сферам жизнедеятельности групп членства показал, что у школьников она в большей степени проявляется в культурно-досуговой, образовательной и социальной сферах. Художественно-эстетическая и спортивная сферы жизнедеятельности находятся на втором месте по популярности, а экономическая, гражданско-правовая сферы и сфера семьи - на третьем. Говоря о студентах, необходимо отметить специфику проявления их социальной активности. Она определяется популярностью иных сфер по сравнению со школьниками, а также различиями у студентов разного пола. Юношам-студентам свойственна социальная активность в профессиональной сфере, а девушкам - в научно-исследовательской и гражданско-правовой сферах.

\section{УРОВНИ СОЦИААЬНОЙ АКТИВНОСТИ МОАОАЕЖИ}

В ряде исследований социальной активности отмечается, что ее уровень может быть определен через группу социально-психологических показателей, таких как отношение к осуществляемой деятельности, инициативность, осознанность приложения своих сил, мотивация и социальная ответственность, включенность в социальное творчество, понимание целесообразности деятельности, ее социальной значимости и полезности (Мальковская, 1988).

В данном исследовании критерием определения уровней социальной активности выступало соотношение степени проявления инициативы и выраженности организаторских способностей. Эмпирически были определены четыре уровня социальной активности. На инициативном уровне установлены высокие значения показателя инициативности при высоких значениях показателя организаторских способностей; на организаторском - низкие значения по инициативности и высокие по организаторским способностям; на исполнительском - средние значения по инициативности и низкие по организаторским способностям; на допустимом - низкие значения по инициативности и по организаторским способностям.

Исследование уровня социальной активности молодежи показало, что большее количество студентов и школьников проявляют социальную активность на исполнительском уровне, они принимают активное участие в мероприятиях, организованных кем-то другим (58 и 60\% соответственно). Однако в зависимости от сферы жизнедеятельности группы и вида проводимого мероприятия школьники активнее, чем студенты, на организаторском уровне (соответственно 34 и 25\%). То есть в условиях современной школы учащиеся имеют больше возможностей для проявления себя координаторами деятельности и организаторами какого-либо вида совместной работы. 
Однако на инициативном уровне, как инициаторы деятельности и активные организаторы мероприятий разной направленности, активность проявляют лишь $10 \%$ школьников и $12 \%$ студентов. Школьников с активностью на допустимом уровне в общей выборке представлено менее $2 \%$, студентов - менее $3 \%$.

Таким образом, проявление инициативы, интерес к определенному виду деятельности, знания, навыки и умения в этом виде деятельности, а также выраженность организаторских способностей определяют уровень социальной активности молодежи в разных сферах жизнедеятельности группы. В исследовании установлено, что студенческая молодежь в большей степени проявляет социальную активность на организаторском уровне. При анализе эмпирических данных с учетом пола респондентов установлено, что чаще выступают в роли организаторов юноши-студенты. Аанный факт подтверждает наличие специфики в социальной активности студентов, так как в школьных группах организаторами мероприятий чаще являются девочки. Кроме того, больше студентов-юношей проявляют активность на инициативном уровне, а для девушек характерна активность на исполнительском уровне, где они готовы оказывать необходимую помощь и выполнять поставленные задачи.

\section{АИЧНОСТНЫЕ ХАРАКТЕРИСТИКИ \\ СОЦИААЬНО АКТИВНОЙ МОАОАЕЖИ}

Аля психологической характеристики социальной активности необходимо понимание свойств и качеств личности, которые составляют ее интегральную часть, характеризуют и раскрывают сущность личности в процессе социального взаимодействия.

В структуре личности можно выделить качества, связанные с социальной активностью. В первую очередь это качества личности, характеризующие поведение человека в отношении себя самого: целеустремленность, активность, самостоятельность, самопознание, любознательность, стремление к материальному благополучию и психологическому комфорту. Во вторую очередь это качества личности, характеризирующие взаимоотношения человека с другими людьми и группой: лидерские качества, общительность, неординарность, коллективизм, взаимопомощь, открытость новому. И наконец, это качества, связанные с общественной жизнью, - активная жизненная позиция, представленность в медиапространстве, ответственность и отношение к труду, стремление иметь высокий социальный статус и популярность, включенность в массовую культуру и др. (Тетерский, 2003).

Анализируя, с какими своими характеристиками, качествами и свойствами личности связывали понятие социальной активности лидеры студенческих групп и школьных классов, можно определить некоторую совокупность характеристик. Аидеры студенческих групп выделили и высоко оценили ряд характеристик личности, важных, с их точки зрения, для успешности деятельности. К ним относятся: инициативность, сила воли, уверенность в себе, настойчивость, ответственность, обязательность, организованность, стрессоустойчивость, хитрость, наглость, чувство долга, решительность, харизматичность. Аидеры школьных групп также отметили данные качества как присутствующие у социально активного человека и добавили к ним еще ряд важных качеств личности, таких как доброта, открытость, исполнительность, аккуратность, справедливость, надежность, пунктуальность.

Таким образом, интегральным качеством личности лидера выступает инициативность. В данном исследовании инициативность рассматривается с двух сторон: с одной стороны, как способность личности к самостоятельности, инновациям, предпри- 
имчивости, с другой - как потребность в активной деятельности. В таком контексте понятие инициативности прежде всего связано с характеристиками делового лидерства. Однако инициативность может иметь социальную направленность и рассматриваться как готовность понимать людей, откликаться, сопереживать, бескорыстно помогать, не быть равнодушным к делам и состоянию других людей. В этом контексте она характеризует эмоционально-социальное лидерство. Типы лидерства в значительной мере связаны с системой ценностных и смысложизненных ориентаций лидера и направленностью его личности и в итоге определяют вектор инициатив и сферы социальной активности.

\section{ЦЕННОСТНЫЕ ОРИЕНТАЦИИ И НАПРАВАЕННОСТЬ АИЧНОСТИ МОАОАЕЖИ С РАЗНЫМ УРОВНЕМ СОЦИААЬНОЙ АКТИВНОСТИ}

Анализ результатов исследования ценностных ориентаций молодежи был проведен в группах респондентов с разным уровнем социальной активности (инициативный, организаторский, исполнительский, допустимый). Были определены система ценностных ориентаций и значимые различия в соотношении ценностей, характеризующих особенности проявления социальной активности у студентов и школьников.

В исследовании установлено, что у студенческой молодежи система ценностных ориентаций представлена следующей иерархией, в которую включены ценности, наиболее выраженные в данной социальной группе:

1) «быть любимым» и «суметь воплотить себя, свои мечты в жизнь»;

2) «быть здоровым» и «иметь интересную работу»;

3) «быть уверенным в своем будущем» и «целеустремленность»;

4) «жизненная мудрость», «достижение высокого общественного положения», «чтобы тебя понимали», «быть уверенным в себе»;

$5)$ «жить жизнью, полной развлечений, удовольствий», «иметь широкий круг общения», «свобода от внутренних противоречий», «быть хорошим специалистом» (Балабанова, 2016).

Анализ ценностных ориентаций студентов с учетом пола респондентов обнаружил различия в их выраженности в группах юношей и девушек. Так, у юношей в большей степени представлены ценности «жить жизнью, полной удовольствий, развлечений» и «свобода от внутренних противоречий» $(\mathrm{p}=0,004$ и $\mathrm{p}=0,0001$, при $\mathrm{p} \leq 0,05$ соответственно), в то время как у девушек наиболее часто встречаются ценности «быть любимым» $(\mathrm{p}=0,0013$, при $\mathrm{p} \leq 0,05)$, «иметь широкий круг общения» $(\mathrm{p}=0,0024$, при $\mathrm{p} \leq 0,05)$, «суметь воплотить себя, свои мечты в жизнь» $(\mathrm{p}=0,0012$, при $\mathrm{p} \leq 0,05)$, «жизненная мудрость» $(\mathrm{p}=0,003$, при $\mathrm{p} \leq 0,05)$.

У студентов, проявляющих социальную активность на инициативном уровне, выявлено сочетание ценностей «суметь воплотить себя, свои мечты в жизнь» и «жизненная мудрость», которые встречаются у них одинаково часто. У студентов с активностью на организаторском уровне определено сочетание ценностей «иметь интересную работу» и «быть хорошим специалистом». Студенты с активностью на исполнительском уровне чаще других обнаруживали сочетание ценностей «достижение высокого общественного положения» и «быть уверенным в себе», а студенты с активностью на допустимом уровне - сочетание «быть любимым» и «жить жизнью, полной удовольствий, развлечений».

Следует обратить внимание на тот факт, что важные для реализации социальной активности и социально значимого поведения ценностные ориентации «принимать 
участие в жизни группы» и «уметь подчинить свои собственные интересы интересам дела» в выборке студентов не представлены.

Систему ценностных ориентаций школьников можно представить в виде следующей иерархии наиболее выраженных ценностей:

1) «быть здоровым»;

2) «принимать участие в жизни группы» и «иметь интересную работу»;

3) «суметь воплотить себя, свои мечты в жизнь» и «уметь подчинить свои собственные интересы интересам дела»;

4) «иметь широкий круг общения» и «жить жизнью, полной удовольствий, развлечений»;

5) «быть любимым» и «чтобы тебя понимали» (Балабанова, 2016).

Анализ системы ценностных ориентаций у школьников разного пола также установил значимые различия в группах юношей и девушек. Так, у юношей чаще встречаются ценности «жить жизнью, полной удовольствий, развлечений» и «иметь интересную работу» $(\mathrm{p}=0,035$ и $\mathrm{p}=0,002$, при $\mathrm{p} \leq 0,05$ соответственно), в то время как девушки в большей степени руководствуются ценностями «быть любимым» ( $\mathrm{p}=0,001$, при $p \leq 0,05)$, «иметь широкий круг общения» $(p=0,027$, при $p \leq 0,05)$, «быть здоровым» $(\mathrm{p}=0,012$, при $\mathrm{p} \leq 0,05)$, «уметь подчинить свои собственные интересы интересам дела» $(\mathrm{p}=0,026$, при $\mathrm{p} \leq 0,05)$.

У старшеклассников, проявляющих социальную активность на инициативном уровне, определено сочетание ценностей «суметь воплотить себя, свои мечты в жизнь» и «уметь подчинить свои собственные интересы интересам дела» как наиболее часто встречающихся. Школьникам с активностью на организаторском уровне в большей степени свойственны ценности «принимать участие в жизни группы» и «иметь интересную работу», а с активностью на исполнительском уровне - «иметь широкий круг общения» и «быть любимым». У школьников, проявляющих активность лишь на допустимом уровне, обнаружено сочетание двух часто встречающихся в данной группе ценностных ориентаций «чтобы тебя понимали» и «жить жизнью, полной удовольствий, развлечений».

Таким образом, особенностью системы ценностных ориентаций школьников является невыраженность ценностей «быть уверенным в своем будущем», «целеустремленность», «достижение высокого общественного положения», а также «быть уверенным в себе» и «свобода от внутренних противоречий».

На основе обобщения данных исследования ценностных ориентаций были определены наиболее распространенные типы направленности личности в разных социальных группах молодежи. Так, у студенческой молодежи преобладает направленность «на себя», на втором месте представлены типы направленности личности «на объект» и «на сохранение отношений», на третьем месте - «на дело» и «на самореализацию». Также важными являются обнаруженные различия в типах направленности личности у юношей и девушек, у первых чаще определялись направленности личности «на объект» и «на сохранение отношений», а у вторых — «на группу» и «на самореализацию». Внимания и дальнейшего исследования заслуживает еще один важный результат - тип направленности личности «на группу» представлен только у студентов, проявляющих социальную активность на допустимом уровне, т. е. у наименее активных студентов, которые в исследуемой выборке составляют небольшой процент. Это может указывать на слабость коллективистских принципов студенческой молодежи, которые являются основой совместной деятельности и со- 
трудничества, взаимопонимания, проявления интереса к другим людям и готовности к помощи.

В исследовании определено, что ведущим типом направленности личности в группе старшеклассников также является направленность личности «на себя». В меньшей степени встречаются типы направленности личности «на другого человека» и «на сохранение отношений», слабо выражены типы направленности личности «на дело» и «на позицию». У юношей-школьников чаще встречаются направленности «на позицию» и «на себя», в то время как у девушек в большей степени представлены направленности «на сохранение отношений» и «на другого человека». Тип направленности личности «на другого человека» встречается только в группе школьников, проявляющих активность на инициативном уровне, которых в выборке всего 10\%. В данной группе школьников ориентация на помогающее поведение и альтруистические тенденции выражены недостаточно (Балабанова, 2016).

Результаты исследования ценностных ориентаций и направленности личности послужили основанием для дальнейшего изучения психологических детерминант социальной активности молодежи, в частности ее мотивации.

\section{МОТИВАЦИЯ СОЦИААЬНОЙ АКТИВНОСТИ}

Опираясь на позицию К. А. Абульхановой-Славской, можно сказать, что в мотивах и мотивации «актуализируется система способов взаимодействия личности с обстоятельствами ее жизнедеятельности и избранный субъектом способ осуществления жизни» (Абульханова-Славская, 1991: 48). В процессе формирования мотивов определяется способ реализации потребностей, который во многом зависит от системы ценностных ориентаций личности, а также от требований обстоятельств конкретной ситуации.

Потребности человека, в том числе социальные, являются важной составляющей мотивации социальной активности и объясняют, почему человек хочет ее проявить. По мнению С. А. Рубинштейна, потребность содержит активное отношение человека, направляющее его на преобразование действительности с целью удовлетворения нужды (Рубинштейн, 2007). Исходя из положения, что значимой для человека целью будет та, которая связана с его потребностями и нуждами, можно сказать, что побуждение к достижению значимой цели и сама цель выступают компонентами мотивации.

Таким образом, мотивация социальной активности, с одной стороны, определяется потребностями, с другой - значимыми целями и намерениями их достичь. Потребности детерминируют поведение человека через систему ценностей, осуществляющих внутренний контроль. В процессе мотивации происходит соединение актуальных потребностей человека и цели как предмета их удовлетворения и формируется способ достижения цели. В итоге способ достижения цели определяется ценностным выбором человека и возможностями ситуации.

В исследовании была определена иерархическая структура мотивов социальной активности студентов. Ведущими мотивами социальной активности студентов являются самореализация (77,2\% респондентов), общение $(76,5 \%)$, обучение $(72,5 \%)$, помощь Аругим $(63,5 \%)$ и сотрудничество во благо $(53,9 \%)$. Аалее по частоте встречаемости представлены мотивы интересного досуга $(50,5 \%)$, дичностного роста и стремления к самостоятельности (46,2\% и 46,1\% соответственно), карьеры $(41,5 \%)$, свободы и созидания чего-то нового (40,05\% и $39,9 \%$ соответственно). Как наименее распространенные определились мотивы служения обществу $(38,5 \%)$, влияния на других 
$(36,2 \%)$, благополучия и престижа $(30,3 \%)$, принадлежности к особому сообществу людей $(25,1 \%)$, ожидания положительной оценки $(19,3 \%)$ и уход от трудностей $(12,4 \%)$.

Ранее проведенные исследования показывают, что ведущими мотивами социальной активности молодежи были узколичностные мотивы, мотивы карьеры и избегания проблем (Федорова, 2000).

Кроме того, анализ мотивации социальной активности молодежи показал статистически значимые различия в женской и мужской выборке по стремлению к свободе, мотивам благополучия и престижа. У юношей они более выражены, чем у девушек, $(\mathrm{p}=0,0047$, при $\mathrm{p} \leq 0,05),(\mathrm{p}=0,002$, при $\mathrm{p} \leq 0,05)$ соответственно. Важным является тот факт, что у юношей также наибольшую степени выраженности имеет мотив ухода от трудностей $(p=0,004$, при $p \leq 0,05)$. Возможно, это свидетельствует о том, что юноши используют социально значимую деятельность как своеобразную копингстратегию. У девушек в большей степени представлены мотивы положительной оценки $(\mathrm{p}=0,003$, при $\mathrm{p} \leq 0,05)$, помощи другим $(\mathrm{p}=0,001$, при $\mathrm{p} \leq 0,05)$ и служения обществу $(\mathrm{p}=0,012$, при $\mathrm{p} \leq 0,05)$, а также определена тенденция к росту значимости для них мотива карьеры.

Одной из задач исследования являлось определение ориентации человека в социальной деятельности на ее процесс или результат. Установлено, что респонденты обеих социальных групп (школьники и студенты) имеют высокую степень выраженности ориентации на результат своей деятельности, причем у девушек данный показатель выше, чем у юношей $(\mathrm{p}=0,004$, при $\mathrm{p} \leq 0,05)$. Возможно, что результат деятельности имеет большее значение для девушек с развитым мотивом карьеры и стремлением к положительному оцениванию другими.

\section{ЗАКАЮЧЕНИЕ}

Психологические характеристики социальной активности, а также ее уровень, формы проявления и мотивация имеют особенности в разных социальных группах молодежи. По ряду содержательных и мотивационных характеристик обнаружены различия, связанные с половой принадлежностью, однако это требует дополнительно исследования с учетом также гендерных особенностей молодежи. Важными психологическими детерминантами социальной активности выступают построение субъектсубъектных отношений в ситуациях социального взаимодействия, уровень овладения социальными навыками и умениями, сформированность личностных качеств, таких как инициативность, сознательность, решительность, самостоятельность, ответственность, свободное мышление и творчество. Выстраивание активной жизненной позиции обусловлено также индивидуально-психологическими и личностными особенностями юношей и девушек и актуальным для них социально-психологическим пространством, где факторами социальной активности выступают условия социальной среды, способствующие или не способствующие проявлению самостоятельности и инициативы, включенность в социальные группы и опыт организации совместной жизнедеятельности.

Таким образом, социально-психологический подход к исследованию социальной активности молодежи может обогатить содержание научных представлений о феномене социальной активности, отраженных в работах других исследователей. Так, большинство существующих исследований социальной активности молодежи можно дифференцировать по двум направлениям. Первое направление объединяет исследования структуры и содержания социальной активности, специфики ее форм, видов 
и уровней в зависимости от видов социально значимой деятельности и степени участия личности в ней. Второе направление представлено исследованиями мотивационно-потребностной сферы личности социально активной молодежи, ее социальных установок и психологических отношений, которые определяют направленность поведения и социальной активности в целом.

Аальнейшее осмысление проблемы психологического содержания феномена социальной активности возможно в направлении интеграции многочисленных точек зрения и разработки социально-психологической теории социальной активности. Необходимость разработки определяется значимостью результатов социально-психологического анализа содержания и структуры социальной активности для понимания ее проявления на разных уровнях, зависимости ее форм от социального опыта, специфики мотивационно-потребностной сферы социально активных и социально пассивных молодых людей, особенностей лидерства, организаторской деятельности, добровольчества, социальной инициативы и творчества.

\section{СПИСОК АИТЕРАТУРЫ}

Абульханова-Славская, К. А. (1991) Стратегия жизни. М. : Мысль. 299 с.

Балабанова, Е. С. (2015) Иичностные и групповые факторы развития социальной активности молодежи // Приоритетные направления развития науки и образования : материалы V Международной науч.-практ. конф. (Чебоксары, 12 июня 2015 г.) / редкол.: О. Н. Широков [и др.]. Чебоксары : ЦНС «Интерактив плюс». 504 с . С. 226-229.

Балабанова, Е. С. (2016) Ценностные ориентации и направленность личности у молодежи с разным уровнем социальной активности // Ценности и интересы современного общества : материалы IV Международной науч.-практ. конф. : в 2 т. М. : Изд-во Московского гуманитарного университета. Т. 1.343 с. С. 83-86.

Журавлев, А. А. (2002) Социальная психология : учеб. пособие. М. : ПЕР СЭ. 351 с.

Косарев, А. С. (1970) Общественная активность сельских школьников // Общественная активность личности и группы школьников / отв. ред. И. А. Френкель. Курск : [б. и.]. 173 с. С. 6-26.

Купрейченко, А. Б., Моисеев, А. С. (2010) Анализ значимости сфер жизни и направлений жизнедеятельности представителей современного городского среднего класса // Знание. Понимание. Умение. № 4. С. 204-209.

Мальковская, Т. Н. (1988) Социальная активность старшеклассников. М. : Педагогика. 160 с.

Парыгин Б. А. (1971) Основы социально-психологической теории. М. : Мысль. 352 с.

Парыгин, Б. А. (1999) Социальная психология. Проблемы методологии, истории и теории. СПб. : ИГУП. 592 с.

Рубинштейн, С. А. (2007) Основы общей психологии : учеб. пособие. СПб. : Питер. 713 с.

Соколова, Е. С. (2010) Представления студенческой молодежи о социальной активности // Социальный мир человека. Вып. 3 : материалы III Всероссийской научно-практической конференции «Человек и мир: конструирование и развитие социальных миров», 24-25 июня 2010 г. Ижевск: ERGO. Ч. I: Направления социальной психологии / под ред. Н. И. Иеонова. 302 с. C. $126-129$.

Тетерский, С. В. (2003) Социальные инициативы детей и молодежи: поддержка общества и государства. М. : Реглант. 214 с.

Федорова, Н. М. (2000) Мотивация участия петербуржцев в волонтерской деятельности // Волонтер и общество. Волонтер и власть : науч.-практ. сб. / сост. С. В. Тетерский ; под ред. $\Lambda$. В. Никитиной. М. : Academia. 152 с. С. 54-58.

Шорохова, Е. В. (1975) Социально-психологическое понимание личности // Методологические проблемы социальной психологии / отв. ред. Е. В. Шорохова. М. : Наука. 204 с. С. 63-71. 


\section{SOCIAL AND PSYCHOLOGICAL APPROACH TO THE STUDY \\ OF YOUNG PEOPLE'S SOCIAL ACTIVITY \\ E. S. BALABANOVA \\ MOSCOW UNIVERSITY FOR THE HUMANITIES}

The social and psychological approach to researching the phenomenon of young people's social activity is based on understanding the importance of social environment conditions, the inclusion of young people in social groups, as well as young people's experience in joint life activity in order to determine the psychological content and structure of social activity in regards to high school and university students. In the research into the psychological traits of social activity displayed by young people belonging to various social groups, the units of analysis are represented by insights into social activity, attitude to various types and forms of social activity, manifestation levels of social activity, as well as young people's value orientations, personal orientation, and social activity motives.

The material for the analysis comprised the results of the author's empirical studies that were conducted in 2014-2017 among school and universities students of Moscow.

Young people's ideas of social activity are stipulated by the forms and types of social activity that are practiced in youth associations and educational institutions, as well as by the spheres of life activity of social groups. The level of young people's social activity is determined by the following factors: proactiveness, interest in a certain activity, its type, knowledge, expertise, and skills in this particular activity, organisational skills. Proactiveness is analysed as an integral quality of a leader's personality and their value orientations and personal orientation are examined as the characteristics that determine the initiative vector, sphere of activity, and types of leadership. The leading personal orientation of socially active young people is self-orientation. The intensity of other types of personal orientation - "outwards", "preserving relationships", "dedicated to a certain action" and "positionbased" depends on the sex of young people and their affiliation to a certain social group. The motives of social activity differ among young people of different sexes and reveal themselves in striving for liberty, wealth and prestige among young males; and social approval, compassion to others, and service to society among young females. Also, young females tend to display higher motivation for career given high significance of the result of the social activity that they are engaged in.

In general, young people's social activity is determined by individual psychological and personal traits of young males and females and the relevant social and psychological environment.

Keywords: social activity; forms of social activity; social activity of young people; levels of social activity; value orientations; personal orientation; motivation for social activity

\section{REFERENCES}

Abul'khanova-Slavskaya, K. A. (1991) Strategiya zhizni. Moscow, Mysl' Publ. 299 p. (In Russ).

Balabanova, E. S. (2015) Lichnostnyye i gruppovyye faktory razvitiya sotsial'noy aktivnosti molodezhi. In: Prioritetnyye napravleniya razvitiya nauki i obrazovaniya: materialy V Mezhdunarodnoi nauch.-prakt. konf. (Cheboksary, 12 iyunya 2015 g.) / ed. by O. N. Shirokov et al. Cheboksary, TSNS «Interaktiv plyus». 504 p. Pp. 226-229. (In Russ).

Balabanova, E. S. (2016) Tsennostnye orientatsii i napravlennost' lichnosti u molodezhi s raznym urovnem sotsial'noi aktivnosti. In: Tsennosti $i$ interesy sovremennogo obshchestva: materialy IV Mezhdunarodnoi nauch.-prakt. konf. : in 2 vol. Moscow, Publ. Moskovskogo gumanitarnogo universiteta. Vol. 1. 343 p. Pp. 83-86. (In Russ).

Zhuravlev, A. L. (2002) Sotsial'naia psikbologiia. Moscow, PER SE Publ. 351 p. (In Russ).

Kosarev, A.S. (1970) Obshchestvennaia aktivnost' sel'skikh shkol'nikov. Obshchestvennaya aktivnost' lichnosti i gruppy shkol'nikov / ed. by Frenkel'. Kursk, s. n. 173 p. Pp. 6-26. (In Russ).

Kupreichenko, A. B. and Moiseev, A. S. (2010) Analiz znachimosti sfer zhizni i napravlenii zhiznedeiatel'nosti predstavitelei sovremennogo gorodskogo srednego klassa. Znanie. Ponimanie. Umenie, no. 4, pp. 204-209. (In Russ).

Mal'kovskaia, T. N. (1988) Sotsial'naia aktivnost' starsheklassnikov. Moscow, Pedagogika Publ. 160 p. (In Russ). 

Russ).

Parygin B. D. (1971) Osnovy sotsial'no-psikbologicheskoy teorii. Moscow, Mysl' Publ. 352 p. (In

Parygin, B. D. (1999) Sotsial'naia psikbologiia. Problemy metodologii, istorii i teorii. St. Petersburg, IGUP Publ. 592 p. (In Russ).

Rubinshtein, S. L. (2007) Osnovy obshchei psikbologii. St. Petersburg, Piter Publ. 713 p. (In Russ).

Sokolova, E. S. (2010) Predstavleniia studencheskoi molodezhi o sotsial'noi aktivnosti. Sotsial'nyi mir cheloveka. In: Materialy III Vserossiiskoi nauchno-prakticheskoi konferentsii "Chelovek i mir: konstruirovanie i razvitie sotsial'nykb mirov», 24-25 iiunia 2010 g. Izhevsk, ERGO Publ. Vol. I. Napravleniia sotsial'noi psikhologii / ed. by N. I. Leonov. Pp. 126-129. (In Russ).

Teterskii, S. V. (2003) Sotsial' nye initsiativy detei i molodezbi: podderzbka obshchestva i gosudarstva. Moscow, Reglant Publ. 214 p. (In Russ).

Fedorova, N. M. (2000) Motivatsiia uchastiia peterburzhtsev v volonterskoi deiatel'nosti. Volonter i obshchestvo. In: Volonter $i$ vlast'. Nauchno-prakticheskii sbornik / comp. by S.V. Teterskii, ed. by L. V. Nikitina. Moscow, Academia Publ. Pp. 54-58. (In Russ).

Shorokhova, E. V. (1975) Sotsial'no-psikbologicheskoe ponimanie licbnosti. Metodologicheskie problemy sotsial'noi psikbologii. Moscow, Nauka Publ. 204 p. (In Russ).

Submission date: 02.06.2018.

Балабанова Екатерина Светославовна - кандидат психологических наук, доцент, доцент кафедры социальной и этнической психологии Московского гуманитарного университета. ААрес: 111395, Россия, г. Москва, ул. Юности, д. 5. Тел.: +7 (499) 374-56-11. Эл. адрес: ebalabanova@mosgu.ru

Balabanova Ekaterina Svetoslavovna, Candidate of Psychology, Associate Professor, Associate Professor, Department of Social and Ethnic Psychology, Moscow University for the Humanities. Postal address: 5, Yunosti St., Moscow, Russian Federation, 111395. Tel.: +7 (499) 374-56-11. E-mail: ebalabanova@mosgu.ru 